\title{
The Tragic Vision of the Matrimonial Relationships in Eugene O'Neill's Family Plays
}

\author{
Bassim Mohammed Dahash Al - Jizani ${ }^{1,2}$ \\ ${ }^{1}$ School of Foreign Languages, English Department, Huazhong University of Science and Technology, Wuhan City, Hubei Province, China \\ ${ }^{2}$ English Department, Collage of Education, University of Basrah, Basrah, Iraq
}

Email address:

jizanie@yahoo.com

\section{To cite this article:}

Bassim Mohammed Dahash Al - Jizani. The Tragic Vision of the Matrimonial Relationships in Eugene O’Neill's Family Plays. International Journal of Literature and Arts. Vol. 4, No. 2, 2016, pp. 20-24. doi: 10.11648/j.ijla.20160402.11

Received: February 26, 2016; Accepted: March 6, 2016; Published: March 23, 2016

\begin{abstract}
Desire Under the Elms (1924), Mourning Becomes Electra (1931) and Long Day's Journey into Night (1941) are very important family plays in Eugene O’Neill. The plays illustrate a tragic vision matrimonial relationship in dysfunctional families at that time. He presents the important tragic visions of the families. This paper proposes O'Neill as the father of modern American drama. This paper also examines and presents crises of familial disintegration of American family.
\end{abstract}

Keywords: Tragic Vision, Ethical Crises, Religion, Emotional Deficiency, Betrayal, Violence

\section{Introduction}

Eugene O’Neill (1888-1953) is the most important twentieth century dramatist in the United States and the only American playwright ever to receive the Nobel Prize and to be awarded the Pulitzer Prize four times. He is considered to be the father of modern American drama for his writing of powerful plays in different styles. He aimed to imbue his work with the tragic sense of life which has its roots in ancient Greek tragedy. O'Neill struggled to create serious American plays, often experimenting with his writing so it would reflect American thought and society; he did this by combining Greek mythology and the family problems seen therein. Between 1916-1920, O'Neill produced a group of one-act plays and completed 20 long plays between 1920 1943. "O'Neill's plays were written from an intensely personal point of view, deriving directly from the scarring effects of his own tragedy of family; so most of his plays, especially the later ones, possess an expression of personal honesty and human passion, reality of family issues rarely found elsewhere in American drama" (Watkinson1980: 12). As a Social critic, O'Neill focuses on familial disintegration in biographical or psychological style. In this paper, tragedy of family issues is illustrated in the three plays: Mourning Becomes Electra (1931), Desire Under the Elms (1924) and Long Day's Journey into Night (1941).

\section{Brief Summary of the Three Family Plays}

Desire Under the Elms (1924) is the first full-length play in which O'Neill successfully evoked the starkness and inevitability of Greek tragedy that he felt in his own life. By drawing on Greek themes of incest, infanticide, and fateful retribution, O'Neill framed his story in the context of his own family's conflicts. "This story is about a lustful father, a weak son, and an adulterous wife who murders her infant son with disregard for relation of her husband" (Tilak1981: 213). Abbie, the mother, is falling in love with her stepson, Eben. In the Greek play Phaedra kills herself in fear that others know her secret; in O'Neill's play Abbie kills her son because she believes that his death will resolve any doubts Eben has about her trustworthiness. The play was acclaimed immediately as a powerful tragedy and has continued to rank among the great American plays of the 20th century.

Another O'Neill's work that has a strong theme of Greek Mythology is Mourning Becomes Electra (1931). It tells the story of a daughter in a strong phase of the Electra complex and a son in an equally strong phase of the Oedipus complex. It also tells of a mother's murder of a father and a son's murder of his mother's lover. "This story is clearly drawn from the Orestes story, a classic Greek myth as well as the 
similar Oedipus myth. Both Greek stories tell of murder among parents as well as excessive love shown to parents by their children" (Goyal1980: 223).

O'Neill's later masterpiece is Long Day's Journey into Night (1941). Significantly, the play deals with the growing pains of a sensitive, adolescent boy characterized by O'Neill. It depicts the agonized relations between father, mother and two sons though its setting span only one day in the life of the family. "The mother was a defeated drug addict, the father a man frustrated in his career and failed as a husband and father, the older son a bitter alcoholic, and the younger son a tubercular, disillusioned youth with only the slenderest chance for physical and spiritual survival" (Bloom1956: 155).

\section{Tragic Vision}

Aristotle defines a tragedy or tragic vision as "an imitation of an action that is serious, complete, and of a certain magnitude; in language embellished with each kind of artistic ornament, the several kinds being found in separate parts of the play; in the form of action, not of narrative, through pity and fear effecting the proper purgation of these emotions" (Butcher 1911: 356). In drama, tragedy treats in a serious and honorable style the woeful or dreadful actions caused by the heroes. Although the word tragedy is often used loosely to sketch any sort of misfortune, it more exactly belong to a literary work that explores with high seriousness affairs with regard to the role of man in the universe. "The Greeks of Attica, the ancient state whose chief city was Athens, first used the word in the 5th century to explain a particular kind of play, which was presented at festivals in Greece". (sharma 1985: 45)

Eugene O'Neill, the first American to succeed in writing tragedy for the theatre, is a serenity of his avowed aim. He examines and explores Freud's concept of the subconscious the equivalent of the Greek idea of destiny like in Mourning Becomes Electra (1931), on Aeschylus's Oresteia. Although the sorrowful feeling of an old or ancient evil is sturdy, the psychological conditioning controls the characters so simply. So, Desire Under the Elms (1924) exhibits a cruel analysis of disintegration in the sexual and greedy tricks of a New England farmers family, unrelieved by manifestations of the transcendent human spirit. In general, the tragic vision, has tended to interpret man from two pettishly opposed points of view. He is exemplified as the God's mage, instinct with grandeur, in which he is illustrated as being, like animals and instinct. O'Neill's vision of life was highly influenced by the Greek's tragedy, which was basically and extremely tragic. O'Neill's Long Day's Journey into Night (1941) is an ideal sample of real tragic vision.

\section{Ethical Crises of Marital Relationships}

Modern drama generally reflects the rise of secularism and moral emptiness. Nevertheless, little has been written to explain what the specific nature of this crisis is. O'Neill's plays are one clear instance of these crises of the modern age by exploring various dimensions of ethical crises, especially the tragedy of marital relationships between the father and mother. In his family plays, the father seems like a compelling character, a unique influence on the other family members, and an important force that shapes the course of the play itself as a central character. O'Neill's plays manifest an aggressive and rebellious impulse against the father. "He seems to have a personal desire to work out his feelings of hostility and manifest his need to escape from the dominating parental influence, and the awe and the overwhelming admiration for his father, James O'Neill' (Weissman1957: 436). O'Neill creates a strong father, who has a very strong relationship to his family, to assist in the plotting of his plays.

The mother is appears as a problematic and tragic image in O'Neill's drama as a manifestation of the female position in patriarchy - absent, silent and indifferent. The plays illustrate the tragedy of family by focusing on the dramatic discourse of the anxious female, who "..... transgress, make trouble, provoke, pervert and turn the representation into a trap" (Christine1988: 13). Most of O'Neill's literary works are set in the home or other domestic situation. Many discussion and literary critics are raised regarding the decline in the traditional role of the father and mother in such an atmosphere and ethical crises of marital relationships such as: declination of religious belief, emotional deficiency, betrayal, and violence.

\subsection{Declination of Religious Belief}

In the $20^{\text {th }}$ century, American families concern themselves with materialistic aspects more than spiritual ones, especially after the Civil War. "The upsurge of secularism itself speaks of the deep decline in religion in human affairs at all levels" (Mahmood 2006: 323). O'Neill's work was written in a decade of women in the U. S. he's got lately their interesting to led the nationalist movement for modern American drama (Zinn 2010: 382) Obviously, if parents do not ingrain ethics and religious belief in their personalities, they will face dilemmas in their lives. O'Neill's plays show that most of parents concern or believe in money, insurance, materialistic issues, lust, and drugs, etc. Although O'Neill himself concerns about religion and spiritual aspects of life, he draws a pragmatic portrait of the American family. The behaviors of the family, who neither care for religious thoughts nor the instructions of the Church, is dependent upon fancies and inclinations. According to Girard, "religion is another term for that obscurity that surrounds man's efforts to defend himself by curative or preventive means against his own fancies and violence. This obscurity coincides with the transcendental effectiveness of violence that is holy, legal and legitimate, successfully opposed to a violence that is unjust, illegal, and illegitimate" (Girard 1984: 204). Also, Mahmood argues the aspect of religious significance in family:

"One major setback that it received pertains to the decline of faith and religion in human affairs, generating spiritual chaos and profound sense of loss at all levels in the society. 
as O'Neill mentions in his plays, this sordid phenomenon owes a lot to the rise of Western philosophical discourses in such areas as psychology, materialism and secularism". (Mahmood 2006: 323)

Alan Scot Willis argues that, the church was only more progressive in its attitude toward racial equality despite its somehow dubious stand before the outbreak of the World War II. They forget the human's conducts and famiy's behaviour" (Willis 2005: 4). Definitely the instructions of religion are very significant for people because it emphasizes good behavior so that their conducts are moderate in society in contrary; some parents' behaviors were not subject to religious restrictions and moral principles. So in the O'Neill's plays, when parents are isolated, their thoughts motivate them to commit mistakes and crimes because nothing can prevent them. Normally, if a person traces his fancies, he may expose himself and his family to troubles and disintegration. For example, in Long Day's Journey into Night (1941), the mother, Mary, is addicted to morphine and the father, James Tyrone, drinks alcohol together with sons without any deterrents. "The drug and alcohol addiction of the Tyrone family is only the surface evidence of the family sickness"(Yussef 1992: 29). In Desire Under the Elms (1924), "Abbie, who betrays her husband, has committed murder, and is responsible for moving passion inside Eben. Also, Abbie's own passion for Eben is the main reason behind the crime committed by her" (Barret1929: 152). The forbidden relationship with her stepson Eben, results in Abbie's pregnancy and killing of the baby. Also, in Mourning Becomes Electra (1931) the mother's murder of father, and the son's murder of his mother's lover.

\subsection{Emotional Deficiency}

O'Neill sketches the husband as incurious person in the family plays. The husband's indifference to his wife illustrates one of the negative images of the American family. Doubtless, the technological development, freedom and selfdetermination contributed to the disintegration of the family and caused a diminution in good relationship within the family. Thus, familial sicknesses appeared such as neglect, absence, emotional deficiency, and so on. In fact, the neglect of a spouse creates a large gap between father and mother. The essential reason, for neglect in a disintegrated family or tragic family is the father's absence from the house for a long time. For instance, in Mourning Becomes Electra (1931), the father, Ezra Mannon, who is a major in the army after his father's death, left the army to study at college. After he finished studying law, he then became a judge. He joined the army again when the Civil War broke out. During all these years he had a bitter experience in marital life, and remained distant from his wife Christine. She wanted him to go away because she hated him. "Ezra Mannon hoped to be killed in action and thought that perhaps Christine also hoped so. $\mathrm{He}$ left Christine alone when he turned back to his home. He engaged with his daughter Lavinia, that is why he preferred to become a lawyer, then a judge and later on a mayor" (Goyal1980: 223).
Undoubtedly, the relationship between spouses will strengthen if there is serious concern in the family. The concern gives them the feeling that each member has mutual love for the other. But in the plays, the husband or the wife does not care for the other spouse. Although the husband does not fully engage in his work, he likes going to rest with friends or stays at work so as not to have to see his wife, even if he finishes his work early. Thus, the wife cannot endure it if her husband enters the house. Because he does not give her kindness and emotion, she definitly looks for someone else to fulfil her requirements and begins to hate her husband. In Mourning Becomes Electra (1931), Christine, the wife of Ezra Mannon, tells him that she does not love him but that she loves another man. In Desire Under the Elms (1924), the father, Cabot Ephraim, is an eccentric, almost endearing old miser and lech. He loves cows, talks to them and sleeps in the barn with them, whereas his wife sleeps alone. "Although Cabot is a deeply religious man, hard, relentless and unforgiving, he neglects his wife's needs, so she lives lonely. Cabot is one of O'Neill's major creations to illustrate the lifedenying sterility of the Puritan ideal" (Tilak1981: 214). In Long Day's Journey into Night (1941), the mother, Mary, is addicted to morphine and neglects the father, James Tyrone, and her two sons, as she does not show enough emotion or give enough love to them.

In the family plays, spouses feel the emotional deficiency; this is one of the main reasons for the familial disintegration as well as for tragedy family. All parents live in a troubled state, if they do not have emotions and love. In Desire Under the Elms and Mourning Becomes Electra, the husband stays at work or with his friends for long times, which makes the wife feel inferior from an emotional perspective. This leads to the internal disintegration of their relations and to disregard for each other. "many expressionist techniques and themes in plays and its' presentation of the unconscious that focus on coducts of spouse" (Galens 2009: 257). O'Neill portrays the father as having no sentimentality with his wife even though she lives with him and obeys him. To continue the relationship, they live tragically in one house for the sake of children. The troubles begin after the feelings of love and emotion fade. The wife, who does not find that her husband provides for her emotions, tries to find another way to fill the deficiency. In Mourning Becomes Electra (1931), "Christine, is out of lack, love and loneliness because of Ezra's absence. She falls in love with Adam Brant, who has professed his love for her to her out of revenge for his mother's suffering. She and Adam show the human traits of love and hate. Christine commits her act of murder out of love for Brant; she plans the murder carefully" (Fleming 1972: 62).

Consequently, the bad emotion inside the wife causes loathing for her husband as in Desire Under the Elms (1924), Abbie hates her husband and she is falling in love with her stepson Eben. "She establishes a forbidden relation with Eben because she has the bad emotion to her husband. Her new loving is to fill her emotional deficiency but not to risk losing the farm when Ephraim dies after she takes the place of Eben's mother. She has sturdy sexual feelings, she is ten 
years older than Eben and she breaks down Eben's resistance and they become lovers in the parlour, which was Eben's mother's special room and which has not been used since her death" (Tilak 1981: 215). In, Long Day's Journey into Night (1941), Mary has no good emotions for her husband and she addicts on morphine's drugs instead of giving love for her family. And in Mourning Becomes Electra (1931), as mentioned above, Christine waits her husband Ezra Mannon to die in order to escape with her beloved because he makes her hates him. Mannon does not have pure or sincere emotions for Christine (Goyal 1980: 230).

\subsection{Betrayal}

Betrayal is very important theme introduced by O'Neill's family plays. O'Neill emphasize on its significant effects on family as negative image of dysfunctional family. As it mentioned, if family don't care for ethical principles and religion, it will disintegrate and lives tragically. In addition, indifference leads to betrayal. Due to a lack of emotions, love, concern, religion and so on between spouses, they will find other ways to fill their deficiencies. In Desire Under the Elms (1924), O'Neill highlights on betrayal as the grave consequences of the tragic incestuous passion that flares between a seductive, young woman and her stepson. Abbie is a wicked, lusty, and extremely beautiful woman that betrays hers husband. In their first encounter Abbie flirtatiously ogles Eben's sexy body, and he unconsciously returns her looks.

Moreover, Cabot betrays his wife Abbie. It is quite satirical that both Cabot and his son Eben patronize the same prostitute. Although Eben hates his father for his immorality, he himself is immoral and corrupt. Eben keeps visiting a whorehouse to sleep with the same prostitute his father sleeps with. The three main characters in Desire Under the Elms (1924) are preoccupied in issues that are far from being noble causes. They betray and fight over sex. O'Neill describes the intense sensuality the Cabot farmhouse is teemed with in terms of animal imagery. O'Neill likens Eben's betrayal with a wild animal to show his strong sensuality and animalistic lust. At first, the two lovers are sexually attracted to each other, and desire seems to sink to a lower level; to that of beasts copulating rather than two lovers making love with affection.

Actually, if the wife feels tragically that the marriage has been ruined, damaged beyond repair, or even if she simply has no desire to try to stay with a man who betrayed her trust, then she can leave her husband. Furthermore, in Mourning Becomes Electra (1931), Christine betrays her husband by having a forbidden relationship with her beloved Adam. Mannon knows his wife's betrayal but he can't prevent her because he can't give her love. So, she hates him and hopes Mannon's death as soon as possible. After she kills her husband, she continues her relation with Adam who gives Christine emotions and love. In addition, different ages may be one of the reasons for the betrayal as in Desire Under the Elms (1924); the husband is much older than his wife at 75 years of age, whereas she was only 35 years old. Therefore, she did not enjoy her life the same as women who enjoy it with their husbands.

\subsection{Family Violence}

O'Neill confirms that violence exists in disintegrated families who do not have love and intimacy. There are two main types of violence: the first is a psychological violence or emotional abuse, which has a greater effect on personality. For example, Cabot in Desire Under the Elms (1924), neglects his wife and make her alone and he talks with his animals more than his wife. In Mourning Becomes Electra (1931), Mannon stays with his daughter's room most of his time. The second one is physical violence or physical abuse which is a more brutal type of violence. Because of father's indifference, the wife will try to find another way to fill her emotions. All the three plays are good examples for different violence, if the wife hates her husband; she might have another relationship with a stranger or kill her husband's son in order to make her husband angry, and so on. Also, she does not care about killing her husband or committing adultery with somebody else. All these types of violence are illustrated in the plays. In Desire Under the Elms (1924), the father beats his sons and the mother, Abbie, asks her husband to be strict with the sons and blames them. Christine, in Mourning Becomes Electra (1931), kills her husband when she gives him poison instead of a cure. And the daughter kills Christine to revenge her father.

F. L. Lucas argued regarding Desire Under the Elms (1924) that "though Eben and Abbie face prison or even hanging for infanticide, they nevertheless are granted a moment of transcendence in the closing moments of the play" (Lucas 1927: 110). Family Violence effects on everyone not just the victim, children are also aware of the violence. Children who grow up in violent homes greatly risk the possibility of emotional, behavioral and physical problems that last for a lifetime. Depression; anxiety; violence toward peers; suicide attempt; drug $\&$ alcohol abuse and running away from home are just some of the issues that stem from the violence in the home.

\section{Conclusion}

O'Neill reveals the tragic vision in his family plays as a strong impressions and images on marital relationship. The father, who is indifferent what is going on inside the house, will put himself in big troubles. There are many reasons reflect bad impressions and troubles in marital relation; the neglect spouse creates a large gap between them. The absence of the father in long time's also causes a lot of conflicts. In $20^{\text {th }}$ century, parents don't inculcate the ethics and Human principles in their personality and children. The religion is very important to human because it emphasizes the best behavior with others. Different ages might be one of the reasons for the disintegration of the family. These reasons cause violence in family, disintegrations, emotional distress, betrayals and crimes in family. 


\section{References}

[1] Ben Yussef, Lamia.1992. Violence in three plays by Eugene O’Neill, Michigan State University UMI.

[2] Butcher, S. H. (1951). Aristotle's theory of poetry and fine art: with a critical text and translation of the Poetics. With a prefatory essay, Aristotelian literary criticism (Vol. 42). Courier Corporation.

[3] Clark, Barret H.1929. Eugene O' Neill: The Man and His Plays. New York: Robert M. McBride and Company.

[4] Dr. Philip Weissman.1957. O'Neill's Autobiographical Drama, Journal of the American Psychoanalytical Association.

[5] Dr. Raghukul Tilak.1981. Desire Under the Elms, RAMA BROTHERS INDIA PVT. LTD.

[6] Dr. B. S. Goyal. 1980. Mourning Becomes Electra, Aarti Book Centre.

[7] F L Lucas. 1927. Tragedy, London.

[8] Fleming Jr. 1972. Tragedy in American Drama: Tragic View. The University of Toledo UMI.

[9] Galens, David. 2009. Literary Movements for Students: Presenting Analysis, Context, and Criticism on Literary Movements. 2nd. Farmington Hills: Gale Print.

[10] Girard, Rene.1984. Generative Violence and the Extinction of social order Salmagundi.

[11] Hall, Ann Christine.1988. The presentation of women in the plays of Eugene O'Neill. The Ohio University.

[12] Harold Bloom. 1956. Eugene O'Neill, Long Day's Journey Into Night, Yale University, Bloom Press.

[13] James Milton Highsmith. 1968. O'Neill's Idea of Theater, South Atlantic Modern Language Association.

[14] Mahmood S, 2006. Secularism, hermeneutics, and empire: the politics of Islamic reformation. Public Culture.

[15] Watkinson, Sharon Anne Onevelo. 1980. An Analysis of characters in selected plays of Eugene O'Neill. New York University, University Microfilms International.

[16] Willis, Alan Scot. 2005 printed. All According to God's Plan: Southern Baptist Missions and Race, 1945-1970. Kentucky: University Press of Kentucky.

[17] Zinn, Howard. 2010. A People's History of the United States. New York: Harper Perennial Modern Classics,. 382. 